\title{
Youth as Producers
}

\author{
Digital Stories of Faith and Life
}

\author{
Birgit Hertzberg KaAre
}

\begin{abstract}
What are the actual inner processes taking place when youth shape and share stories about their lives through digital storytelling? In the present study, we follow an experiment in religious education in a local congregation outside Oslo. In the autumn of 2005, the Church of Norway initiated a project wherein young people raised questions of faith and life in short biographical mini-films called 'Digital Faith Stories'. As the title suggests, digital tools are central to the project. We focus on the youth participants, analysing their role as media producers and following the construction of their stories. The adult leaders of the project are also given some attention. The analysis shows that the method of 'Digital Storytelling' might lead to a more systematic educational method for including the lifeworld of the young in religious training. The research has been carried out in cooperation with Prof. Knut Lundby.
\end{abstract}

Keywords: digital storytelling, religious education, life stories, youth as producers

\section{Introduction}

The study of the uses and consequences of new media for leisure time, family life and the peer relations of young people has become an important field of research (Drotner, 1999; 2001; Heim et al., 2007; Kaare et al., 2007; Ling, 2006; Livingstone, 2002; Livingstone \& Bovill, 2001). In modern Western societies, the emergence of new multimedia cultures is crucial to the lives of children and young people. As a result of their relations to digital technology, children and young people play, learn, communicate, work and shape their social and cultural relations in quite different ways than did their parents (Kaare, 2004). In recent years, several researchers have paid special attention to the development of media participation among young people, and actual participation in media production has been assigned great importance (Carlsson, 1999). Due to interactive media technologies, the younger generations in media-saturated countries have become, to a large extent, active and quite proficient media users (Drotner, 2001).

The digital revolution has been accompanied by an explosion of digital means by which young people produce and distribute stories and pictures of themselves (Scheit, 2006; Denzin, 2001). Young people's self-representations are to be found in various digital genres, above all on different forms of social network Internet sites (boyd \& Ellison, 2007; Lenhart \& Madden, 2007; Ogan, 2006; Polak, 2006; Scheit, 2006), but also in more modest genres such as the types of digital stories we are going to present here.

Educators are benefiting from the new digital tools. Much research has been done on the impact of new media and digitalization in schools and education (Buckingham, 2003; 
Drotner, 2001; Gilje, 2005; Süss, 2001; Østerud, 2004). In recent processes of diversification of learning, the sites of education are changing, as well as the forms (Buckingham, 2003: 189-203). Informal learning is regarded as increasingly important in learning processes (Buckingham, 2003: 196-199; Drotner, 2006). Nevertheless, as learning is increasingly associated with digital technology, new sites and the leisure culture of the young are currently integrated into formal education, even religious education in Norway.

\section{Experiments in Religious Education}

In 2003, the Norwegian Parliament decided to fund a reform of religious education. Religious education is regarded as a task for the churches and religious communities, not for the public schools, as was the case until 1969. Currently, the Church of Norway is undergoing a period of experimental and developmental work. Its teaching focuses on key dimensions of human life, and its activities aim to stimulate the formation of a (religious) identity for young people to help them both master their lives and understand their cultural heritage and religious traditions. The Church of Norway has launched a five-year developmental period under the logo 'The greatest of all' [Størst av alt].

Here, we wish to present an experiment within this reform, for which the uses of digital media and digital tools are essential. Among a variety of different educational projects, in the autumn of 2005 the Church of Norway initiated an experiment on digital storytelling, where youth are encouraged to produce a short self-representational mini-film using the narrator's own voice. These films are called 'Digital Faith Stories' and are constructed within a specific genre of 'Digital Storytelling', which has evolved for several years as a media practice around the world (Hartley \& Mc William, forthcoming; Hull, 2003; Hull \& Nelson, 2005; Hull \& Katz, 2006; Lambert, 2006; Meadows, 2003; Thumim, 2006). This 'Center for Digital Storytelling' model, which will be discussed in more detail later on, has been adopted in education elsewhere, especially in the US, where some practitioners use it as a method of building engagement and multimedia literacy.

When we look at the learning aspects of religious education, some special conditions deserve note. Unlike education connected to school systems, the religious education of members of the Church of Norway is voluntary and informal. It does not involve examinations, and it is usually associated, and in competition, with the leisure activities of the young. These conditions make religious education a challenge for teachers and supervisors as regards the use of pedagogical principles and the specific goals of education. If they do not succeed in their efforts to please young participants, children and youth might disappear to join other, more attractive, arenas of leisure activities. This is a real problem for the Church of Norway, as recruitment to this institution is at stake. The experiment of using digital tools in the learning process is an effort to reach the young by using cultural expressions familiar to them.

In the following, we will focus on the youth participating in the project, analysing their role as media producers and following the construction of their stories. Here we raise two key questions:

- What are the actual processes taking place when youth shape and share stories about their lives through digital storytelling?

- What are the consequences of introducing informal experiments such as 'Digital Storytelling' to educate young people in existential subjects such as faith and the mastering of life? 


\section{Theoretical Aspects}

The specific case in focus can be analysed from different angles (Kaare \& Lundby, 2008; Lundby \& Kaare, 2007). Theories of youth culture and identity constructions, as well as the concepts of 'lifeworld' and of 'late modernity', are all relevant to the analysis of the present case (Drotner, 1999; Fornäs et al.,1993; Habermas, 1987; Heggen \& Øia, 2005; Ling \& Helmersen, 2000; Livingstone, 2002; Ziehe, 1995; 2001; Øia \& Fauske, 2003), and we will briefly consider some of them in our discussion of the empirical data. However, the perspective we wish to focus on here, above all, is how the method of Digital Storytelling influences the learning process.

The emergence of new media cultures has definitely changed old hierarchical patterns of knowledge transmission and teaching, both within the family and in schools, ever since children and young people achieved skills in using digital media technologies (Gee, 2003; Himanen, 2001; Holm Sørensen, 2000; Kaare, 2004; Prensky, 2006). New generations are often optimistically ascribed ICT competence mostly owing to their young age (Jessen, 2000:149; Johansson, 2002:124; Papert, 1993; Tapscott, 1998). Young people's changing media environments have led researchers to claim that new media, particularly computers and the Internet, are accompanied by new forms of literacy (Livingstone, 2002:214), variously labelled 'media literacy', 'digital literacy' or the more limited 'digital competence'. In Scandinavia, researchers have developed the concept of literacy to include the German concept 'Bildung' (or the Scandinavian equivalents bildning, dannelse, or danning). Bildung is a wider concept than literacy. At the beginning of the $20^{\text {th }}$ century, acquiring Bildung above all meant learning to master inner collective common values such as control, dignity, obedience and grace (Drotner, 2006: 1). Today, the concept implies reflection, criticism, identity, competence and sense of community, and also, in the case of religious Bildung, experienced belief (Søbstad, 2006).

For generations, religious education in Norway represented a hierarchical transmission of Christian knowledge, which has been traditionally associated with an ancient, authoritative tradition and fixed content. Teaching aimed at formalized verbal correctness and strict social control of the behaviour of children and youth, and education was clearly more oriented towards the benefits of the collective than of the individual (Johnsen, 1993). Although, in recent decades, the focus of education has moved towards participation in the Christian community, the Norwegian educationalist Frode Søbstad questions the still-prevalent intellectual focus of such education. The main goal of the afore-mentioned educational reform is to hand down the Christian religious heritage to new generations, and to highlight central dimensions of human life. The aim is to tie instruction, knowledge and critical reflection together with experience and participation (Størst av alt, 2003: 4, 9). According to Søbstad, formulations such as these show that the reform may have the potential to become an arena of Bildung towards Christian conviction (Søbstad, 2006: 8). Here, we intend to analyse the consequences of rethinking in the education of religion and to see whether the experiment of 'Digital Storytelling' has the potential to be characterized as Bildung in religious education.

\section{The Case}

The case is located in the parish of Haslum, close to Oslo, Norway. This is an area with a high level of both income and education. Twenty-three young people between 16-18 years produced digital stories throughout the period 2005-2007. They created 29 digital stories altogether, while the adult leaders of the experiment produced 4 . We finished 
collecting our field data for the present chapter by interviewing youth from the first two groups participating in the project in 2005 and 2006. We also interviewed the youth minister who left the project after this period. ${ }^{1}$ We are still observing the activities and collecting all the stories produced (2007-2008). Recruitment of young people to the project has been difficult. Because of the high level of income in this area, the project has to compete with a variety of leisure activities offered to the young. The youth participating in the project have a stronger personal connection to the church than do most young people in the area. They all attend high school; some of them go to special classes for media education.

The philosophy behind the Digital Storytelling concept is to enable people without a technical background to produce works that tell a story, using moving images and sound; however, the youth in our case are, on the whole, media literate. They are not especially preoccupied with digital technology as such, but digital tools are quite naturalized into their everyday lives. One of the female storytellers characterizes the event about which she is making her story as 'one of the bookmarks of my life'. She is learning media at school, and she feels very familiar with digital expressions, which she characterizes as 'modes that have no limits, a very fine way of mediating things'.

\section{Research Methods and Ethics}

We have decided to apply the perspective of the actors to the analysis of the empirical material. Therefore, much of our data derives from reflexive, in-depth interviews with the narrators of the digital faith stories. A self-reflexive approach like this is an important element in many media pedagogical works (Buckingham, 2003; Gilje, 2005: 50). Eleven of the fourteen young storytellers who took part in the project in 2005 and 2006 agreed to be interviewed (eight girls and three boys). We asked them questions about their experience of the process of creating their stories, what inherent meanings they ascribed to them (Rooth, 2005), and how they felt about sharing their personal narratives with others.

We also interviewed the leaders who made their own digital stories. While the youth were interviewed individually, the leaders were interviewed both individually and in a focus group, and they were also invited to a seminar to discuss the project. We took great care not to pass on information to the leaders that could be connected to a specific young narrator, but we discussed the progression of the project with them on a more general level. One of us is also active on the board of the project. Overall, these methods of research involved us in the foundational development of the project. In this way, we may have had some influence on the interpretations and expectations of the leaders, concerning both how the project should be understood and how it should be run.

The methods of data triangulation described above are of course very subjective, but for this reason our study soon turned into a process of increasing our own comprehension and it helped us develop a holistic perspective on the project. Through the individual interviews, we gained important insight into the lifeworld (Habermas, 1987) of the youth, their experiences of the process of creating the Digital Faith Stories and the individual values and meanings they ascribed to their stories. And in an extensive focus group interview with the supervisors after the first production was finished, we focused on their expectations before the project started, their experiences of being supervisors of an experiment with many undefined means and goals, their future aspirations for the next productions, and their efforts to develop a new digital genre, which they called 'Digital 
Faith Stories'. Looking at the responses, it is clear that much of the insight we gained using this data collection method would not have been articulated even to the leaders without the focus group interview and the seminar we arranged.

Both the case project (run by the Church of Norway) and the research project (run by the University of Oslo and funded by the Research Council of Norway) have been conducted according to strict governmental guidelines, given by the Data Inspectorate, designed to protect the privacy of the individual. The producers of the Digital Stories own the copyright of their digital objects. The supervisors, as well as Norwegian authorities (The Data Inspectorate), put restrictions on dissemination of the digital narratives, due to privacy guidelines for topics related to religion. When the present article was written, in June 2007, four DVDs, containing 33 stories all together, were produced and given to selected persons for use on appropriate occasions, mostly for educational purposes within the congregation. Some of the digital stories were even used for special occasions in the church, such as the confirmation service.

\section{Digital Faith Stories}

'Digital Storytelling' is both a method and a movement intended to give people a voice through the use of computer tools, and the narratives are usually produced in a workshop (Lambert, 2006). Digital Stories are a genre of mini-films, told in the first person, using the creator's own voice. The story defines and leads all aspects of the process. Pre-existing visual archives, i.e. the family album and home video, inspire the stories, which usually last for 2-3 minutes (Lambert, 2006: 45-60). To discuss their ideas, the storytellers are taken through a group script review process called 'The Story Circle'. For the actual production, they use standard software such as Adobe PhotoShop and Adobe Premiere. The finished stories are shared in a final presentation.

The method used for telling 'Digital Faith Stories' mainly follows this strict pattern of form. Participants avoid experiments with the form as they wish to ensure the quality of the final product. When it comes to form, the 'Digital Faith Stories' produced so far cannot be distinguished from other digital stories that follow the format outlined at the Center for Digital Storytelling (CDS) in California. The paradigmatic principles of 'Digital storytelling', as developed by the Center are, in short, that:

1. Everyone has a powerful story to tell.

2. Listening is hard. Stories unveil themselves in the encounter with an audience.

3. We all see, hear, and perceive the world in various ways, making our stories different.

4. Creative activity is human activity. Telling stories is part of this creativity.

5. The computer, with all its limitations, is a powerful instrument for creativity.

'Digital Faith Stories' as such are a non-existent genre so far, at least when judged by the outer form of the produced stories, but the intention of the project leaders is to develop a new genre. As one of the supervisors put it when the first round of production was finished, 'It is important not to make copies of stories already accepted as true stories of faith. We are not interested in stories like testimonies that are more outspoken and instructive'. Another supervisor said, 'The first DVD shows that we are in the midst of a process. By the end of the year, we will have 30 stories, next year we will have 
$60 \ldots$ 'The first DVD was regarded as a piece of apprenticeship. In contrast to the stories produced by the leaders, just a few of the stories produced by the youth openly referred to religious matters. Even so, the stories are interpreted in their context as faith stories both by the leaders, the young narrators and even by the congregation. This specific religious meaning of the produced digital stories can only be found by analysing their context, above all in relation to the importance ascribed by all participants to the method of creating the stories used in the story-circle and the workshop.

The digital faith stories are socio-cultural constructions. Guided by the adult leaders, the youth construct a multimedia self-representation. They search for relevant motifs that would make a good story - for pictures to illustrate or expand the perspective of the narrative as well as for sounds and artefacts that can be used together to construct a multimodal expression of an aspect of their life story. The youth are encouraged to develop a story based on some experienced event from their life.

\section{The Content of the Narratives}

Regarding the content, the Church is open to a variety of contents and individual meanings in the mini-films produced by the young. In principle, all stories by the young are to be accepted by the supervisors. When choosing the themes of their narratives, the young storytellers felt free to use whatever subject was important to them. 'We just made a film about something we thought was important in life', one of the girls said. 'But the supervisors managed to focus on belief', she added.

When supervising the youth, the adult leaders did not push them to talk about religious belief in the context of their Digital Stories. Speaking of one's personal belief is not customary among most Norwegians. The supervisors did not want to tell the youth what they should believe; 'We are working hard to elicit the thoughts they might have... They have to experience it [belief] themselves... It has to be experienced as true,' they said. The content analysis shows that there are few explicit meaning statements or references to religion or the sacred in the stories produced by the youth. Except for a few narratives, the Digital Faith Stories approach questions of faith through the 'belonging' aspect of religion (Lundby \& Kaare, 2007). Several of the young people put more or less hidden signs of belonging to the church in their films: there are pictures from their confirmation; one uses a bracelet with 'What would Jesus do?' on the personal photographs; another shows pictures from the congregation's billiard room.

A content analysis of the stories reveals that the explicit content varies greatly; what they have in common is that they are all based on the personal experiences of the storytellers. When looking for the implicit content of the stories, they obviously have a great deal in common. Mastering life is a central theme in the stories produced by the youth; as young people, they have to struggle with growing up. In looking for the leading motif in their stories, the Leitmotiv, questions of existential importance are striking in most of the 29 stories produced so far; they are identity works on 'being me'. Three aspects of this identity-shaping project are prominent. First, the youth talk about the choices they have made or have to make in their own lives. Second, they talk about their own performances in song, dance, swimming, rock or a television quiz. Through portrayal of their own performances, they use their films to share the experience of mastering something, an experience that scholars regard as key to the identity process (Heggen \& Øya, 2005). Performing is a visible form of mastering. Third, several of the stories tell about strong relationships - not the 'weak ties' of contemporary network society 
(Granovetter 1973), but the strong ties related to your best friends, an older cousin or a friend who died.

The young storytellers focus, in their individual stories, on subjects of urgent importance to them, such as the mastering of their existence, their life projects and their identity developments. All of their stories end with a positive statement, which they worked out together with the adult leaders in the workshop. In giving the stories a positive ending, the idea was to help the young better master their life by producing positive stories, stories that might also be helpful to other young people. The leaders' intervention in the process of creating the digital faith stories influences the choice of theme, as well as the content and structure of the stories.

\section{The Digital Dynamics}

What are the actual processes through which youth shape and share stories about their lives in digital storytelling? The supervisors' reflections, based on the first production of Digital Faith Stories, give important information about the digital dynamics of storytelling. The supervisors hold that the process of digitalization, like using one's own voice and own photos, gives young people an opportunity to construct stories that they never would have told without these technological tools. The supervisors regard the Digital Faith Stories as a valuable and relevant mode of expression, culturally familiar to the youth because of its multimodality. In one of their latest promotional flyers, they present the making of a film using digital tools as a goal in itself. One of the supervisors says that the use of digital tools in religious education is a great idea: 'I regard the digital tools as a catalyst, which is part of the process and pushes the process on'.

One main purpose of the in-depth interviews was to help the young filmmakers reflect on issues that might concretize the digital dynamics of this educational experiment. One of the girls said that, to her, the learning process of making the film was exciting: 'It was not difficult, but exciting to learn something new. Moreover, it was great fun to make a film. There are many [young people] who have not made a film before. It is a bit advanced to make a film. I felt cool making my own film'. Clearly, the excitement of creating a film is the central motive for partaking in the project, not the use of digital tools as such.

One of the girls explicitly claimed that the use of digital tools, in contrast to face-toface communication, makes it easier to express what she wants in her story. The pictures make it easier: "'Pictures say more than a thousand words". That is what I have heard. [...] When I look at the pictures, I get ideas or remember things', she said. One of the boys indicated that digitalization is essential because it enabled him to share his story with many: 'Many [young] people will watch the stories. They will be more exciting [because they are digitalized]. And since the form is fixed, it will not alter from time to time.' What these young people emphasize about their use of digital tools connects the digitalization process of their stories to values such as being cool, to personal excitement, and above all to the satisfaction of being able to communicate with other young people using audiovisual expressions known within youth culture today.

\section{Avoiding the Aesthetics of Boredom}

When asked if Digital Faith Stories could help to renew the aesthetic forms used by the Church of Norway today, one of the supervisors said they could and insisted that digitalization is important, because 'a whole generation thinks the church service is deadly boring ... because the forms of expression are old fashioned'. He has observed 
that the young filmmakers do not invest a great deal of reflection on the meaning of faith, not even on the importance of these Digital Faith Stories: 'They join to have an experience. They join what they think is fun. They go where something is happening; "Here are computers, here it is camera-fun". They go where it is interesting and exciting to be'. What he has observed should no doubt be considered in relation to the mediatized (Hjarvard 2008) leisure culture of young people.

One of the girls confirmed that the perspective of aesthetics is important to youth. When asked about her opinion of the use of digital tools in religious education, she said, 'I think it's smart, because the Church has always been rather boring and out of date in certain areas. Therefore, it's a bit of a revolution that it's become more technical, that you use a video camera and editing in the church. I think it's great'. She said that the process of creating Digital Faith Stories gives her a new perspective on faith and on the Church: 'Christianity is not just boring and dogmatic. I mean, it is a bit of the future in this [project], that they don't cling to the idea that nothing should be digital or technological'. One of the main arguments for using digital tools in religious education is the possibility of presenting aesthetic forms that are familiar in the youth culture instead of using forms that young people conceive of as boring and out-of-date modes of expression.

\section{Towards a Christian Bildung}

The aim of the educational reform is to tie instruction, knowledge and critical reflection together. Does this turn from a traditional culture of teaching to a modern mode of learning change the mentality and pedagogical principles of religious education? What are the consequences of introducing informal experiments such as Digital Storytelling to educate young people in existential subjects like faith and the mastering of life?

\section{Lifting the Veil}

In the Digital Faith Stories project, the learning process works both ways -analysis of the present case shows that sharing experiences through the stories is very important. This very special method of sharing introduces the Church to a new pedagogical principle. One of the supervisors described the new principle as follows: 'We should put away our own voices ... there are more voices coming into the Church, the voices of young people. The Digital Faith Stories are lifting the veil. They help us figure out what young people think, what is going on inside them'. Another adds, 'We will gain unique knowledge about youth.' The supervisors would like to integrate this knowledge into their further teaching.

The special method of sharing inherent in creating Digital Faith Stories could be characterized as a process of developing the faith of the youth, and thus a synergetic effect is produced. This project has long-term potential because the supervisors work with other projects in the congregation as well; they accumulate experiences that they can then use in other types of religious education. Young people's inner thoughts about the mastering of life, about their faith and their beliefs, i.e. the lifeworld of the youth (See Habermas 1987, Ziehe 2001), as they are expressed in the Digital Faith Stories and in the workshops in the project, are in this way handed back to the collective memory of the congregation. The supervisors think that what they learn from the Digital Faith Stories could benefit the Church, and that their experience with this type of learning could be used in other congregations as well. 


\section{A Method of Bildung?}

Explicit references to faith are rare in the mini-films of the young. Nevertheless, the process of creating Digital Faith Stories has an implicit learning aspect in relation to faith - not in the formal teaching of faith, but in developing faith. The supervisors indicated that 'the faith story' of an individual is not a fixed story; it is a process that goes on for years. Therefore, when teaching youth, what they try to avoid is to push for quick results about verbalizing faith more explicitly.

The formulations of one girl reveal that her own learning process could be classified as a classic process of Bildung: ' ... after having made one [digital story] I felt much more mature, and I feel that from the time when we started [until now... I I have developed a lot. Before, I was maybe not very sure about myself and my own faith. Now I feel more convinced. I think it's great fun to make such films; and I want to make more of them', she said. In evaluating the project, she explained that most important to her is '...the opportunity to develop oneself and one's own faith. It is an enormous process of becoming mature, where you notice what you feel and believe, and you are always confronted with new aspects. And then you see what you believe in'.

The Digital Faith Stories produced so far end with a kind of 'punch line'. Here the storytellers' reflections are condensed into a statement that focuses on existential themes such as dreams for the future, joy, curiosity, friendship and love. One concluded, 'I don't regret my choice. ... What is the meaning of life, if it isn't to follow a dream?' Another said, 'Singing and listening to music make me happy. I know that whatever I'll do, songs will always mean something to me'. A third ends the story about her cousin by expressing how important it is to have a close relative and a close relationship. The above quotes show that the Digital Faith Stories actually focus on the main values presented in the slogan of the educational reform: 'Faith, Hope and Love'. These Christian values are concretized in the mini-films and worked out as personal narratives, highlighting questions of the individual mastering of life. The focus of the educational experiment is on Bildung, more on identity and reflection than on learning some specific knowledge (Søbstad, 2006). The process of Bildung is thus unquestionably visible in the project.

\section{The Church and Youth of Late Modernity}

One overall question posed here is whether the Church of Norway has managed to incorporate the youth culture of today and the cultural traits of late modernity into their reform. The Church of Norway has long understood the need to alter their religious education and has gradually opened up to include rather modern cultural expressions in the education of the young. What is radically new and experimental in the Digital Faith Stories project is a learning process that has shifted away from the transmission of knowledge and towards a Christian Bildung. The Church's reorientation towards open-minded listening to the voices of young people, talking about such fundamental questions as the mastering of life and individualized understandings of faith, is quite noteworthy.

When supervisors accept the creativity of youth, and want to enhance their own competencies, they learn about new, individual perspectives on faith through the production of the Digital Faith Stories. This does not mean that their own faith is at stake, but the Digital Faith Stories reveal young people's reflections and give adults insight into their own lifeworld. Often, adults do not easily achieve such insights, especially not those who have a position as teachers of religion, who are supposed to pass on the 'right' beliefs and the authorized words. 
The experiment of creating Digital Faith Stories might be seen as an embodiment of the meeting between the traditional Church culture and the strong cultural forces of late modernity. One consequence of this meeting can be seen in the transformation of the communication process - from handing over the authoritative heritage of knowledge of the right way of interpreting faith and living your life, to the reciprocal communication of individual interpretations and meanings, so characteristic of the reflexivity of late modernity. The Digital Faith Story method is well suited to incorporating the dominating cultural forces of late modernity. It is individualized, because it takes as its starting point a personal narrative. The content is often fragmented and disparate, because the raw material consists of individual life experiences. The method is anti-hierarchical in structure, because it is based on the notion that all voices should be heard, even the voices of youth and children. It also accepts the otherness of the young, by insisting that all voices are valuable and worthy of being heard in their own right. According to several scholars, characteristics such as these are the very essence of late [or post-] modernity (Buckingham, 2003:58-61; Drotner, 1999; Livingstone, 2002). Furthermore, according to Ziehe, the cultural complexity of late modernity is above all to be seen in the youth culture (Ziehe 1995, 2001; Drotner 1999:17).

\section{Reflections on a Case in Progress}

This specific case is only one limited attempt to experiment with method in religious education in the Church of Norway. The present experiment is not meant to replace more traditional forms of religious education, but to supplement them. Analysis of the case shows that reciprocity of communication, between supervisors and young students, may lead to a more systematic educational method for including the lifeworld of the young in religious training. The method of active listening by all parties replaces the hitherto prevailing communicative forms of traditional preaching, or more personal testimonies, both of which are more a question of one-way communication and pedagogical authority than are the experimental digital stories, which are open to different interpretations. We observe a transformation of the communication process from handing down the authoritative heritage of knowledge, to the reciprocal communication of the individual interpretations and meanings that characterize late modernity.

Changes in the communication process such as these benefit both the religious collective and the individual students. The religious collective, the leaders and the active participants in the congregation have entered a long learning process by listening to the Digital Faith Stories produced by the young members of their congregation. Younger points of view on faith and life, as expressed in the mini-films, are integrated by the older generations into their teaching and into how they deal with young people in their daily work, even into their conception of what might constitute faith and what meaning religion might have.

The present educational experiment makes evident the tension between tradition and modernity in religious education, and points to the importance of integrating the modes of digital expression into religious education in general. The analysis indicates that the Church of Norway may be able to adjust to the culture of late modernity. The youth culture of today, characterized by individualization, privatization, and a lifestyle dominated by leisure activities and heavy use of the media and ICT, has been incorporated into this experiment, which has increased supervisors' understanding of the lifeworld of the young people they are educating. Both sides benefit from this dialogue. 


\section{Note}

1. The project may take a new direction, as the adult supervisors for 2008 are all new.

\section{References}

boyd, d.m. \& Ellison, N.B. (2007) 'Social Network Sites: Definition, History, and Scholarship', Journal of Computer-Mediated Communication 13(1), article 11. http://jcmc.indiana.edu/vol13/issue1/boyd.ellison. html, 2008-01-16.

Buckingham, D. (2003) Media Education. Literacy, Learning and Contemporary Culture. London: Polity Press.

Carlsson, U. (1999) 'Foreword', in Feilitzen, C. von \& Carlsson, U. (eds.) Children and Media. Image - Education - Participation. Göteborg: Nordicom, pp. 9-12.

Center for Digital Storytelling / CDS, www.storycenter.org, 2008-01-16. www.storycenter.org/principles.html

Denzin, N.K. (2001) Interpretive Interactionism ( $2^{\text {nd }}$ ed.) Thousand Oaks, CA: Sage.

Drotner, K. (1999) Unge, medier og modernitet - pejlinger i et foranderligt landsskab. Gylling: Borgen/Medier.

Drotner, K. (2001) Medier for fremtiden: børn, unge og det nye medielandskap. København: Høst og Søn.

Drotner, K. (2006) 'Dannelse for fremtiden: Tre teser om mediernes plads i de gymnasiale uddannelser', http:// www.fremtidensdanskfag.u-net.dk/kortlagning/kirstendrotner.htm, 2008-01-16.

Feilitzen, C. von \& Carlsson, U. (eds.) (1999) Children and Media. Image - Education - Participation. Göteborg: Nordicom.

Fornäs, J., Boëthius, U. \& Reimer, B.(1993) Ungdomar i skilda sfärer. FUS-rapport nr. 5. Stockholm: Brutus Östlings bokförlag.

Gee, J.P. (2003) What Video Games Have to Teach us about Learning and Literacy. New York: Palgrave Macmillan.

Gilje, Ø. (2005) Digital sjangerlek på nye laringsarenaer. En evaluering av mzoon, et medieverksted på nett. Oslo: ITU.

Granovetter, M. S. (1973) 'Strength of Weak Ties', American Journal of Sociology, 78(6), pp. 1360-1380.

Habermas, J. (1987) The Theory of Communicative Action, Lifeworld and System: A Critique of Functionalist Reason, Vol. 2, Boston: Beacon Press.

Hartley, J. \& Mc William, K. (forthcoming) Story Circle. Digital Storytelling Around the World. Malden, MA: Willey-Blackwell.

Heggen, K. \& Øia, T. (2005) Ungdom i endring. Mestring og marginalisering. Oslo: Abstrakt forlag.

Heim, J.; Brandtzæg, P.B.; Kaare, B.H.; Endestad, T., \& Torgersen, L. (2007) 'Children's Usage of Media Technologies and Psychosocial Factors', New Media \& Society Vol.9 (3), pp. 49-78.

Himanen, P. (2001) The Hacker Ethic and the Spirit of the Information Age. London: Vintage.

Hjarvard, S. (2008) 'The Mediatization of Society', Nordicom Review no. 2. Gothenburg: Nordicom.

Holm Sørensen, B. \& Olesen, B.R. (red.) (2000) Børn i en digital kultur-forskningsperspektiver. København: Gads Forlag.

Hull, G. (2003) 'At last, Youth Culture and Digital Media: New Literacies for New Times', Research in the Teaching of English. Vol. 38( 2), November, pp. 229-233.

Hull, G. \& Katz, M.-L. (2006)'Crafting an Agentive Self: Case Studies of Digital Storytelling', Research in the Teaching of English. Vol. 41(1), August 2006, pp.43-81.

Hull, G. \& Nelson, M.E. (2005) 'Locating the Semiotic Power of Multimodality', Written Communication 2005; Vol. 22; pp. 224-261.

Jessen, C. (2000) 'Det kompetente børnefellesskab. - Leg og læring omkring Computeren', in Holm Sørensen, B. \& Olesen, B.R. (red.) Børn i en digital kultur - forskningsperspektiver. København: Gads Forlag, pp. 147-161.

Johansson, B. (2002) 'Daddy is Second on the High Score List - Constructions of Childhood and Adulthood in Computer Contexts', in Hauan, M.A. \& Heggli, G. (ed.) Younger than Yesterday, Older than Tomorrow. Cultural Perspectives on Contemporary Childhood and Youth. Åbo (NFF Publications 11.) pp. 101-130.

Johnsen, B.H. (1993) Konfirmasjon og erindring. Konfirmasjonens betydning i et livsløpsperspektiv. Pakt 4. , Arkiv for kirkehistoriske tradisjoner. University of Oslo (Dr.diss.).

\section{Acknowledgement}

This research is being carried out in cooperation with Professor Knut Lundby. Our case study is part of a larger research project called 'MEDIATIZED STORIES. Mediation perspectives on digital storytelling among youth', funded by the Research Council of Norway 2006-2010 http:// www. intermedia.uio.no/mediatized/. 
Kaare, B.H. (2004) Ungdom som lever med PC. Oslo: Norsk institutt for forskning om oppvekst, velferd og aldring (NOVA Rapport nr 2).

Kaare, B.H., Brandtzæg, P.B., Heim, J. \& Endestad, T. (2007) 'In the Borderland between Family Orientation and Peer-culture: The Use of Communication Technologies among Norwegian Tweens', New Media \& Society, Vol. 9(4), pp. 603-624.

Kaare, B.H. \& Lundby, K. (2008) 'Mediatized Lives: Autobiography and Assumed Authenticity', in Lundby, K. (ed.) Digital Storytelling, Mediatized Stories: Self-Representations in New Media. New York: Peter Lang.

Lambert, J. (2006) Digital Storytelling. Capturing Lives, Creating Community (2nd ed.). Berkeley: Digital Diner Press.

Lenhart, A. \& Madden, M. (2007) 'Social Networking Websites and Teens: An Overview', in Pew Internet \& American Life Project. http://www.pewinternet.org/pdfs/PIP_Teens_Social_Media_Final.pdf, 2008-01-16.

Ling, R. (2006) 'Mobile Emancipation: Children, Youth and the Mobile Telephone', in Drotner, K. \& Livingstone, S. (eds.) International handbook of Children, Media and Culture. London: Sage.

Ling, R. \& Helmersen, P. (2000) "'It Must be Necessary, it has to Cover a Need": The Adoption of Mobile Telephony Among Pre-youth and Youth', Presented at the Conference on the Social Consequences of Mobile Telephony, 16 June 2000, Oslo.

Livingstone, S.(2002) Young People and New Media. Childhood and the Changing Media Environment. London. SAGE.

Livingstone, S. \& Bovill, M. (eds.) (2001) Children and Their Changing Media Environment. A European Comparative Study. London: LEA

Lundby, K. \& Kaare, B.H. (2007) 'The Sacred as Meaning and Belonging in Digital Storytelling', in Furseth, I. \& Leer-Salvesen, P.: Religion in Late Modernity. Essays in Honor of Pål Repstad. Trondheim: Tapir Academic Press, pp. 69-86.

Meadows, D. (2003) 'Digital Storytelling: Research-based Practice in New Media', Visual Communication. Reflections on Practice, Vol. 2(2). London: Sage, pp. 189-193.

Ogan, C.L. \& Cagiltay, K. (2006) 'Confession, Revelation and Storytelling: Patterns of Use on a Popular Turkish Website', New Media and Society 2006, Vol. 8(5), pp. 801-823.

Papert, S. (1993) The Children's Machine. New York: Harvester Wheatsheaf.

Polak, M. (2006) 'It's a gURL Thing: Community Versus Commodity in Girl-Focused Netspace' in Buckingham, D. \& Wilett, R. (eds.) Digital Generations. Children, Young People and New Media. London: Lawrence Erlbaum Ass., pp. 177-191.

Prensky, M. (2006) 'Don't Bother Me Mom - I'm Learning!' How Computer and Video Games Are Preparing Your Kids For Twenty-first Century Success - and How You Can Help! Minnesota: Paragon House.

Roth, W.-M. (ed.) (2005) Auto/Biography and Auto/Ethnography: Praxis of Research Method. Bold Visions in Educational Research Vol. 2. Rotterdam: Sense Publishers.

Scheit, L.A. (2006) 'Adolescent Diary Weblogs and the Unseen Audience', in Buckingham, D. \& Wilett, R. (eds.) Digital Generations. Children, Young People and New Media. London: Lawrence Erlbaum Ass., pp.193-210.

Süss, D. (2001) 'Computers and the Internet in School: Closing the Knowledge Gap?', in Livingstone, S. \& Bovill, M. (eds.) Children and Their Changing Media Environment. A European Comparative Study. London: LEA, p. 221-242.

Søbstad, F. (2006) ‘Trosopplæring som danningsprosjekt. Læring i kirken sett i et utvidet perspektiv’, Foredrag på fagkonferanse for det nasjonale kompetansenettverket for trosopplæring, Oslo 2006-03-23.

Tapscott, D. (1998) Growing Up Digital. The Rise of the Net-Generation. New York: Mc Graw-Hill.

Thumim, N. (2006) 'Mediated Self-Representations: "Ordinary People" in "Communities"', in Herbrechter, S. \& Higgins, M. (eds.) Returning (to) Communities. Theory, Culture and Political Practice of the Communal. New York: Rodopi, pp. 255-274.

Ziehe, T. (1995) Ambivalenser og mangfoldighed. København: Politisk Revy.

Ziehe, T. (2001) 'De personlige livsverdeners dominans. Ændret ungdomsmentalitet og skolens anstrengelser', Uddannelse nr. 10, 2001. http://udd.uvm.dk/200110/udd200110-01.htm?menuid=4515, 2008-01-16.

Øia, T. \& Fauske, H. (2003) Oppvekst i Norge. Oslo: Abstrakt forlag.

Østerud, S. (2004) Utdanning for informasjonssamfunnet - den tredje vei. Oslo: Universitetsforlaget. 